Research Report No. 46/2009

\title{
Proportionality Analysis as an Analytical Matrix' Adopted by the Supreme Court of Mexico
}

Amaya Alvez Marin

Follow this and additional works at: http:/ / digitalcommons.osgoode.yorku.ca/clpe

\section{Recommended Citation}

Marin, Amaya Alvez, "Proportionality Analysis as an 'Analytical Matrix' Adopted by the Supreme Court of Mexico" (2009).

Comparative Research in Law \& Political Economy. Research Paper No. 46/2009.

http://digitalcommons.osgoode.yorku.ca/clpe/154 


\section{Comparative Research in Law \& Political Economy}

Amaya Alvez

Proportionality Analysis as an 'Analytical Matrix' Adopted by the Supreme Court of Mexico

EDITORS: Peer Zumbansen (Osgoode Hall Law School, Toronto, Director, Comparative Research in Law and Political Economy, York University), John W. Cioffi (University of California at Riverside), Nassim Nasser (Osgoode Hall Law School, Toronto, Production Editor) 

CLPE Research Paper 46/2009

Vol. 05 No. 09 (2009)

\title{
Amaya Alvez
}

\section{Proportionality ANALYSIS AS AN 'ANALYTICAL MATRIX' ADOPTED BY THE SuPREME Court OF MeXico}

\begin{abstract}
This paper explores proportionality analysis as a constitutional standard that allows courts to engage in a public conversation, especially with the legislature. This conversation would consider the concept, structure and normative force of fundamental rights, the way in which two or more rights compete and collide, and as to how a particular disagreement about rights can be addressed. What is particularly appealing is the way in which this approach to proportionality analysis does not prescribe any legitimate means 'per se'. It is relational because it must apply the means to achieve a particular aim in a real situation and decide if the sacrifice applied to a particular right is proportionate. This may eventually offer better public engagement with judicial arguments and endorse judicial independence by rendering the decision more structured, open and transparent.

A further aim of this paper is to fulfill the knowledge gap about the migration of proportionality analysis as a rights adjudication mechanism to Latin America and, at the same time, make a claim for a context-sensitive approach. The hope is that judiciaries will learn from recent pitfalls that occurred under authoritarian regimes in Latin America where decisions were based upon excessive formality and disregard of relevant factors involved in rights claims. The recent adoption of proportionality analysis by the Mexican Supreme Court in 2007 has created the option of a new appraisal of its migration to Latin America.
\end{abstract}

Keywords: Constitutional rights - migration of adjudication mechanism- proportionality analysis JEL classification: K40

Amaya Alvez

Associate Professor of Law, School of Law, Faculty of Juridical and Social Studies, School of Law, University of Concepción, Chile; PhD candidate, Osgoode Hall Law School, York University, Canada. 


\section{Proportionality ANALYSIS AS AN 'ANALYTICAL MATRIX' ADOPTED BY THE SUPREME COURT OF MEXICO ${ }^{1}$}

Amaya Alvez*

\section{INTRODUCTION}

Throughout the $20^{\text {th }}$ century, Latin America presented a conundrum concerning the role of judiciaries as a branch of government and, in particular, their protection of the population's fundamental rights. Throughout post-independence Latin America in the 1800s', judiciaries were constructed as mechanical 'law appliers' allowing them to adjudicate rights in a constrained, highly formalist approach to the law. The textualist system of interpretation ended up neglecting the very nature of the constitution as the fundamental or supreme legal text that contains the political and legal accords to rule a certain society. With the existence of political subrepresentation under 'democratic covers' and a strong Spanish monarchical heritage, the result was a judicial system traditionally deficient in its protection of fundamental rights. Decisions were only grounded in positive laws that failed to provide accountability and deepened the democratic deficit of the judiciary as a branch of government. ${ }^{2}$ Arguably, the main challenge was the judiciary's own understanding as to their role and that of the courts within a democratic political system. One line of reasoning advanced in this article explains that judges possessed a deferential attitude in human rights adjudication through the misuse of rule-like adjudication mechanisms, called subsumption, when constitutional rights are considered to be rules. The preference for such a method of legal argumentation is rooted in the formalism of the civil law tradition and the search for certainty and predictability in the role of judges as merely 'law appliers.' ${ }^{3}$ The downside of its use at the constitutional level in the Latin American context was that judgments became mechanical and poorly reasoned and did not take into account all relevant factors from political, social, cultural and economic perspectives.

\footnotetext{
* Associate Professor of Law, School of Law, Faculty of Juridical and Social Studies, School of Law, University of Concepción, Chile; PhD candidate, Osgoode Hall Law School, York University, Canada.

${ }^{1}$ I am indebted for the thoughtful comments of the members of the Toronto Group Workshop and to the participants of the Agora Academy 2009 at LSE in which a draft of this paper was presented. I highly appreciated editorial advice received from professors Shin Imai and Jennifer Nedelsky.

${ }^{2}$ For a general description on the Spanish government in America see: JAVIER BARRIENTOS, EL GOBIERNO DE LAS INDIAS [THE INDIAN GOVERNMENT] (MARCIAL PONS- FundACION RAFAEL DEL PINO 2005).

${ }^{3}$ An important factor to bear in mind throughout this paper is the legal tradition in all Latin America called the Civil Law Tradition, in contrast with the common law tradition. Differences exist mainly in the historical understanding of the nature of law and the role law played in society and its political organization. The Civil Law Tradition is the older and the more widely distributed on earth. Authors like John Merryman fixed the date of its origin in 450 B.C., the date of the publication of the Twelve Tables in Rome. It is the dominant legal tradition in Europe, all Latin America, part of Asia and Africa and even enclaves in the common law world like Quebec in Canada and Puerto Rico and Louisiana in the United States. John Henry MERryman \& Rogelio PÉrez-PERdomo, The Civil LaW Tradition: An Introduction to the Legal Systems of Europe AND LATin AMERICA 2 (3 ${ }^{\text {RD }}$ ED. 2007) (STANFORD UNIVERSITY PRESS 2007).
} 
Proportionality, as an alternative way to adjudicate rights, is considered part of the transformation of constitutional law in the second half of the $20^{\text {th }}$ century. Proportionality analysis is presented as a conceptual framework, an analytical methodology, and a legal construction that defines the relationship between human rights and considerations that may justify their limitation in a democracy. ${ }^{4}$ Nevertheless, as a standards-based mechanism that seeks direct application of background justifications to the search for a stronger form of judicial discretion, proportionality analysis has intensified the debate regarding judicial power. As a balancing mechanism, it is seen as the threshold applied to a state action that will first seek to interpret the scope of a constitutional right and then places limitations upon it at the subconstitutional level. Whether or not the measure adopted is justified is based upon the relationship between the means used and the aims pursued by the state act through an analysis of the legality and legitimacy of its content.

\section{THE RULE-BASED WAY OF CONSTITUTIONAL RIGHTS ADJUDICATION IN LATIN AMERICA}

The Latin America method chosen to solve disagreements about rights was a rule-based system of adjudication. Robert Alexy presents this system as an approach that considers rules as definitive commands that 'contain fixed points in the field of the factually and legally possible. ${ }^{5}$ The latter is based upon the idea that legal validity does not accept degrees and, therefore, a legal rule is either fulfilled or not. ${ }^{6}$ Judges confronted with such a system must use the traditional canons of interpretation to solve questions connected with the application of constitutional rights, including grammatical, historical or systematic elements. The objective is to provide greater certainty in the outcome and ensure that the constitution and the norms contained in it are considered to be rules to provide legal predictability. However, the complexity of constitutional rights, as a particular form of legal norms, does not allow them to be considered solely as rules (an argument that will be developed further in this paper). The normative solution created to overcome the collision of rules is that of 'categorization'. A conflict between rules can only be solved through a formal exception, implying that one of the rules will not be applied or will be

\footnotetext{
${ }^{4}$ Aharon Barak, Former President of the Israeli Supreme Court, AnNual Lecture in Law and Society, THE Foundation FOR LAW, JUSTICE AND SOCIETY IN ASSOCIATION WITH THE LAW FACULTY AND CENTRE FOR

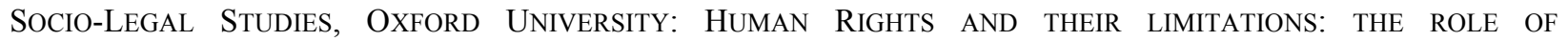
PROPORTIONALITY (JUNE 4, 2009). Available at http://www.fljs.org
}

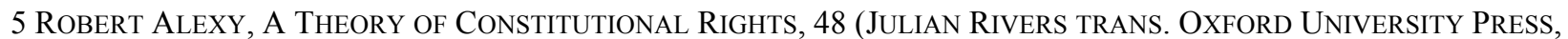
2002).

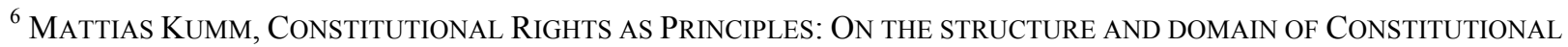
JUSTICE, 2 (3) I.CON 574-96 (2004) (discussing the relevance of Alexy's work through a review essay on his book 'A Theory of Constitutional Rights'). 
declared invalid. Categorization imposes a hierarchy upon rights with one rule regarded as superior to the exclusion of another.

Subsumption, as the mechanism used by judges to apply rules, is a deductive formula where the legal judgment follows logically from the description of the case and the existence of a norm. 'As John Merryman described it, "[t]he whole process of judicial decision is made to lift into the formal syllogism of scholastic logic. The major premise is in the statute, the facts of the case furnish the minor premise, and the conclusion inevitably follows." 8 The use of subsumption as the sole mechanism to solve collisions between constitutional rights is seen as problematic by Robert Alexy. This is based on the belief that this deductive structure does not take into account all of the relevant factors at stake. Secondly, he claims that the legal and factual premise used to construct the formula should also be justified. ${ }^{9}$

Frederick Schauer offers a more positive account by claiming that subsumption, as a rights adjudication mechanism, is closer to the formality of the law than balancing. He describes subsumption as 'largely constrained, largely textually interpretative, and largely characterized by the way in which the constraints of a moderate clear text, exclude numerous factors and considerations that would be otherwise relevant. ${ }^{10}$ For Schauer, the extent to which the deductive formal structure of subsumption constrains the decision-makers [judges] is an empirical inquiry dependent upon the availability of choices, the level of binding to the rules at stake, and the formal and linguistic range of choices allowed by that legal rule. ${ }^{11}$

In Latin America, the use of subsumption as a formal logical structure to solve conflicts between constitutional rights resulted in the courts imposing a hierarchy of values and identifying the higher value in the hierarchy in any given case. Although it is acceptable for a hierarchy to be constructed between guaranteed constitutional rights in a constitutional setting and, as a rule-based system, can provide greater certainty to the outcome when adequately constructed, these decisions can be negatively critiqued. The decisions (a) were poorly reasoned with rare reference to, or argumentation on, the substantive content of the rights involved (a discussion that would construct the preferred hierarchy), the scope of the rights protected by the constitution, the extent of legal protection that the rights will have in the legal system, and the possibility and standard to which rights could be limited; (b) made no interrelation between the rights, with no acceptance that constitutional rights can collide nor how to solve these collisions; and (c) contained no reasoning as to whether a modification of the factual data would affect the result of the case.

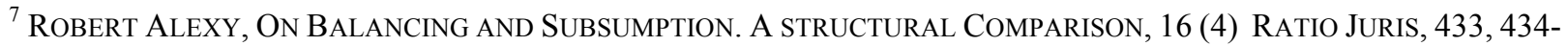
35 (DECEMBER 2003).

${ }^{8}$ MERRYMAN \& PEREZ-PERDOMO, supra note 3, at 36.

${ }^{9}$ ALEXY, supra note 7 , at 435 .

${ }^{10}$ Frederick Schauer, Balancing, Subsumption, AND the CONSTRAining Role Of Legal TeXt (February 18, 2009). Available at SSRN: $\underline{\text { http://ssrn.com/abstract }=1403343}$

${ }^{11}$ SCHAUER, supra note 10 , at 15.
} 
I propose that the use of subsumption in Latin America, combined with the postindependence conception of the judiciary and the influential Spanish heritage, encouraged the judiciary to remain detached from the social-political process, marginalized judges from the social changes that occurred, and promoted minimal judicial discretion with failure to account for decisions adopted.

\section{THE GLOBAL DEVELOPMENT OF THE CONCEPT AND STRUCTURE OF PROPORTIONALITY ANALYSIS}

Another way to adjudicate constitutional rights and to construct limitations upon them is the use of proportionality analysis presented as a judicially-created doctrine of constitutional law. In other words, proportionality analysis is a way to assess the conformity of laws with constitutional norms with special attention to rights. Proportionality analysis is considered a methodological criterion or standard, generally understood as being when state power may encroach upon individual freedom only to the extent that it is indispensable for the protection of the public interest'. ${ }^{12}$ The underlying idea is that measures adopted by authorities should not exceed the limits of what is considered appropriate and necessary in order to obtain constitutionally legitimate aims in the name of society.

The difference between subsumption and proportionality can be presented as part of a broader debate between rules and standards. ${ }^{13}$ Authors, like Frederick Schauer, have argued that standards-like proportionality systems and rule-based systems will converge towards a rule-like structure as it matures, provided by the example of the method of adjudication under the First Amendment in the United States. ${ }^{14}$ This contention can be challenged based on the spread of the standard-based proportionality analysis in the last 50 years. The German Basic Law of 1949 established the parameters of a limitation to a fundamental right. This was pursued by a reflective adoption in 1965 where the German Constitutional Court anchored the principle of proportionality in the Rule of Law and considered it to be an unwritten principle of constitutional law. ${ }^{15}$ For Alec Stone and Jud Mathews, the adoption of proportionality in Germany during the late 1950's occurred because of the structure of constitutional rights adopted in the 1949 Fundamental Law and the Civil Legal Tradition. This is in contrast to modern thinking where the strongest argument for upholding proportionality as the main rights adjudication doctrine is

\footnotetext{
12 Nicholas Emiliou, The Principle of Proportionality in European Law: A Comparative Study 23 (KLUWER LAW INTERNATIONAL EDITIONS, 1996).

${ }^{13}$ Pierre Schlag, Rules and Standards, 33 UCLA LAW REVIEW, 379, 379-430 (1985-1986).

${ }^{14}$ Frederick Schauer, The CONVERGEnCE OF Rules AND StANDARDS, N.Z. L. REV. 303, 303-28 (2003).

${ }^{15}$ BVerfG Dec. 15, 1965 BVerfGE 19, 342 (348-349).
} 
based in the rationality of its structure and the outcomes as a real guarantee of constitutional rights. ${ }^{16}$

Following the development of proportionality within German constitutional law, the principle was then adopted by many European countries and by the European Union. ${ }^{17}$ Other countries, like Canada, ${ }^{18}$ have used the proportionality analysis since the 1980s. After spreading in Europe, it was adopted more recently in Latin America by countries like Colombia ${ }^{19}$ in the 1990s and México ${ }^{20}$ in 2007. The authors claim that, by the end of the 1990s, every effective system of constitutional adjudication in the world, with the exception of the United States, had embraced the main tenets of proportionality analysis. ${ }^{21}$

The use of proportionality analysis assumes an active role for judges in constitutional adjudication and the consideration of constitutional rights as a particular set of legal norms, whether that be principles or rules. For Alec Stone and Jud Mathews, constitutional judges employ proportionality to achieve two goals; to 'manage potentially explosive environments, given the politically sensitive nature of rights review, and to establish and reinforce the salience of constitutional deliberation and adjudication within the great political system. ${ }^{22}$ This is also developed by Simon Evans and Adrienne Stone claiming proportionality as a standards-based technique that resists resorting to rules. The explanation offered by these authors is based upon the example provided by Canada with the use of proportionality analysis based on Section 1 of the Charter and the 'Canadian Legal Culture'. The argument is that the application of proportionality analysis, as a judicially-made flexible doctrine, can be anchored in the Canadian openness to contemplate foreign laws and the practice of comparative constitutional law by scholars and, most significantly, the courts. ${ }^{23}$ The analysis of constitutional rights and its limitations requires the involvement of all branches of government bringing relevance to the

16 Alec Stone Sweet \& Jud Mathews, Proportionality Balancing and Global Constitutionalism, 47 COLUM. J. TRANSNAT'L L. 72, 97-111 (2008-2009) .

${ }^{17}$ About proportionality analysis in Europe see: EVELYN ELLIS, THE PRINCIPLE OF PROPORTIONALITY IN THE LAWS of Europe (Hart Publishing, 1999) and Nicholas EMiliou, The Principle of Proportionality in European LAW: A COMPARATIVE STUdy (KLUWER LAW INTERNATIONAL, 1996).

${ }^{18}$ The leading case is R. V. OAKES [1986] S.C.J. No 7; [1986] 1 S.C.R. 103 for a treatment of its evolution see SUJIT CHOUDHRY, SO WHAT IS THE REAL LEGACY OF OAKES? TWO DECADES OF PROPORTIONALITY ANALYSIS UNDER THE CANADIAN CHARTERS's SECTION 1, 34 S.C.L.R. (2 $\left.2^{\mathrm{ND}}\right)$, 501-535 (2006).

${ }^{19}$ For a comprehensive study of the use of the proportionality principle in Colombia see: CARLOS BERNAL PULIDO, EL DERECHO DE LOS DERECHOS ( $3^{\text {RD }}$ ED. UNIVERSIDAD EXTERNADO DE COLOMBIA, 2006).

${ }^{20}$ The 'juicio de amparo en revisión 1659/2006' decided by the Supreme Court of Mexico in 2007 introduced formally the principle of proportionality as a'analytical matrix' as the judges called it.

${ }^{21}$ STONE \& MATHEWS, supra note 16 , at 77-79

${ }^{22}$ STONE \& MATHEWS, supra note 16 , at 87.

23 Simon Evans \& Adrienne Stone, BALANCing AND Proportionality: A Distinctive EThic?, PAPER PRESENTED AT THE VII WORLD CONGRESS OF THE INTERNATIONAL ASSOCIATION OF CONSTITUTIONAL LAW, ATHENS, 11-15 JunE, 2007. Available at http://www.enelsyn.gr/en/workshops/workshop15(en).htm 
notion of 'dialogue' between the courts and legislature. ${ }^{24}$ A reason offered is the particular understanding of the way in which the relationship between the judiciary and the legislature should be driven, as an example Peter Hogg and Allison Bushell consider proportionality analysis as one way in which a dialogue between parliament and the court can occur. ${ }^{25}$

The other important element to take into consideration is the way in which proportionality analysis structures a relationship between constitutional principles and rules articulated as constitutional rights, and balances the individual interest with the collective one. Robert Alexy conceptualizes constitutional rights as principles which 'require that something be realized to the greatest extent possible given the legal and factual possibilities. ${ }^{26}$ Therefore, principles appear to contain an open possibility of what is legally and factually available which, in my opinion, is one of the characteristics that makes proportionality attractive. Principles are considered prima facie reasons for norms and are never definitive. From Alexy's perspective, conflicts between two principles can only be resolved through balancing in a specific context because principles can be satisfied to varying degrees. The purpose of balancing is to resolve conflicts between principles, but it also provides assistance to state organs to optimize rights properly. Presented with two colliding principles, the solution is provided through weighing the particular circumstances of the case. Neither principle will be regarded as pre-eminent with the result being dependent upon the context. A collision between two principles is solved by establishing a 'conditional relation of precedence' between the principles in light of the circumstances of the case. Different principles will prevail under different circumstances. Robert Alexy offers a first "law of competing principles" as part of his theory of principles where, "[ $t]$ he circumstances under which one principle takes precedence over another constitute the conditions of a rule which has the same legal consequences as the principle taking precedence."27 The resulting consequence is that a constitutional right will be considered as a principle at first sight but, following the consideration of the legal and factual circumstances and the competing principles, it will only be transformed into a rule valid in some cases. Therefore, balancing of principles produces rules through proportionality analysis. When a constitutional court transforms a principle into a rule, it is a judicial attempt to declare what the constitution stipulates in that particular setting. However, principles remain vivid and demanding in the background of the rule decided through precedence.

A further element is the relationship between the global and the local. Part of the attractiveness of proportionality analysis is its ability to be used as a descriptive tool for rights

\footnotetext{
${ }^{24}$ This has been extensively discussed in Canada see Peter Hogg \& Allison Bushell, The Charter Dialogue BETWEEN COURTS AND LEGISLATURE (OR PERHAPS THE CHARTER OF RIGHTS ISN'T SUCH A BAD THING AFTER ALL), 35 Osgoode Hall Law Journal, 75 (1997) and the updated version Peter Hogg, Allison Bushell \& Wade

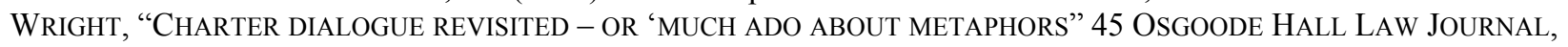
1 (2007).

${ }^{25}$ Peter Hogg \& Allison Bushell, The Charter Dialogue between Courts and legislature (OR Perhaps THE CHARTER OF RightS ISN'T SUCH A BAD THING AFTER ALL), 35 OSGOODE HALL LAW JOURNAL, 75, 82 (1997).

${ }^{26}$ ALEXY, supra note 5, at 48 .

${ }^{27}$ ALEXY, supra note 5, at 54.
} 
adjudication claims. Proportionality allows consideration of real situations and not simply abstract arguments or public policy discussion. Supporters of proportionality analysis focus upon a case-by-case analysis that creates space for a public conversation about the concept, structure and normative force of fundamental rights. David Beatty presents proportionality as a principled, pragmatic and, therefore, legitimate review process. He sees proportionality as a response to various constitutional problems, arguing that, "on a shrinking planet, [proportionality] is appropriately multicultural. It structures an integration of the real and the ideal, the local and the universal, by integrating a fundamental principle of distributive justice into each community's understanding of itself.",28 Proportionality is presented as a formal framework of analysis that orientates judges as to how to organize and evaluate conflicting factual claims that are made about the laws they are asked to review. A flip side of Beatty's approach is Vicki Jackson's critique of his argument. She says that prior questions about the degree and tradition of legal protection accorded to different individual rights, and the institutional roles of non-judicial decision-makers, have not been acknowledged in Beatty's account. ${ }^{29}$ For Jackson, the differences in outcome are not due to different interpretative methodologies of the courts but rather sociological understanding of the relationship between law and society in that particular constitutional order. Jackson underlines the advantages of proportionality analysis as being the increase in transparency of judicial decision-making by the creation of a framework or structure, the attention paid not only to the individual interests at stake but also to governmental justifications, and the attention paid to particular facts transforming proportionality into a more flexible tool of adjudication. For Jackson, proportionality is a relevant tool in constitutional adjudication but, at the same time, she believes that it is necessary to remember that constitutions serve a number of purposes and that those principles, values and rights are protected with consideration of the particular characteristics of a polity. Therefore, her invitation is to combine proportionality with institutional considerations in a State-by-State analysis. ${ }^{30}$

At a national level, proportionality analysis assists in the creation of an open framework for the judge, where the normative content of a particular fundamental right must be constructed. From my perspective, proportionality as a tool for constitutional adjudication is an invitation for judges to argue the fundamental social agreements considered in the constitution. Moreover, proportionality used in an ordered form can assist judges by structuring their decisions, provide transparency in the legal reasoning used and, as a consequence, allow a better public engagement with judicial arguments which, finally, improves the accountability of the judiciary as a branch of government.

\footnotetext{
${ }^{28}$ David Beatty, The Ultimate Rule of LaW 168 (Oxford University Press, 2004).

29 Vicki C. Jackson, Being Proportional about Proportionality 21 Const. Comment., 803, 821 (2004) (book review of 'The Ultimate Rule of Law' by David Beatty).

${ }^{30}$ JACKSON, supra note 29 , at 859.
} 
[VoL. 05 No. 09

\section{THE ADOPTION OF PROPORTIONALITY ANALYSIS AS RIGHTS ADJUDICATION DOCTRINE IN MEXICO}

The 'juicio de amparo en revisión 1659/2006' decided by the Supreme Court of Mexico in 2007 formally introduced the principle of proportionality as an 'analytical matrix' in rights adjudication claims. ${ }^{31}$ The case involved a young soldier called Esteban Cabrera who was dismissed from the military after being diagnosed as being HIV positive. The case was presented as a constitutional collision between the societal interest, represented by the constitutional principle of capacity of the military forces to carry out their duties and the integrity of its members and, on the other side, the individual interest of Esteban Cabrera based on his guarantees of equality and non-discrimination grounded on health reasons. Dismissal from the military as a consequence of a positive test had been established by statute through the law governing the social security system of the Mexican armed forces. ${ }^{32}$ The declaration written in Esteban Cabrera's medical certificate was 'useless or incompetent in the second category' with the effect being his compulsory retirement from the armed forces. Because he had only served six years, he did not receive a pension or health coverage after his retirement.

In February 2007, the Supreme Court of Mexico, as the adjudicating court in constitutional cases, used proportionality analysis as the chosen mechanism to overcome the constitutional collision at stake. The case was presented as the limitation imposed on the individual right of Esteban Cabrera to equality and non-discrimination, grounded on health reasons and his HIV status, in order to allow the full protection of the societal interest in having efficient military forces. The issue before the Court was whether the law concerning the social security system of the Mexican armed forces, approved in 2003, represented a reasonable and proportional limitation to the constitutional rights of equality (Article $4^{\circ}$ ) and non-discrimination based on health reasons $\left(\right.$ Article $1^{\circ}$ ) of Esteban Cabrera. The Supreme Court accepted that the law was disproportionate and, therefore, unconstitutional. As a consequence, Esteban Cabrera was reinstated to his position prior to the proceedings as an active member of the armed forces and was to receive all of the legal benefits related with this declaration (for example, an income and health coverage).

The preliminary question that the majority decision had to examine, as the first step of proportionality analysis, was whether the state action pursued a constitutionally legitimate aim capable of justifying a limitation upon human rights. The term 'margin of appreciation' was first developed by the European Court of Human Rights to refer to the room given to the political representatives of signatory countries in order to fulfil their obligations under the European Convention on Human Rights. Over time, the term has been extended to refer to the discretion

\footnotetext{
${ }^{31}$ This is a legal mechanism created by the Mexican Constitution in order to claim that state acts in general and legislative acts in particular violated constitutional guarantees.

${ }^{32}$ Law of the 'Instituto de Seguridad Social para las Fuerzas Armadas Mexicanas,' published at the Official Gazette on July 9th, 2003, [Hereinafter ISSFAM law.]
} 
national courts permit the executive and, primarily, legislature to exercise with regard to the scope of legal protection each constitutional right will enjoy in a given legal order. Critics have argued that this approach could be used by courts deferential towards national political representatives to avoid the implementation of international standards of enforcement of human rights. $^{33}$

Through this first step, the Supreme Court of Mexico examined whether the law governing the social security system of the Mexican armed forces [ISSFAM law] had a constitutionally legitimate aim in dismissing a member of the Armed Forces as a consequence of being HIV positive. The Court established that the law had a constitutionally legitimate aim in ensuring the efficency of the military forces and protecting the integrity of its members. Justice Jose Ramon Cossio Diaz did say that the efficiency of the Armed Forces could be challenged as a principle of the Mexican constitutional order. Unfortunately, for the sake of the argument developed in this paper, this opinion was published as a personal opinion in a Mexican magazine and not within the judgment. ${ }^{34}$ Justice Cossio argues that articles 4, 13, 31, 32, 123 part B, XIII and 129 of the 1917 Constitution treats subjects as different by permitting the existence of Military Tribunals, establishing the armed forces as mandatory, requiring serving members to have been born in Mexico, and creating a special system of social welfare for its members. Therefore, this makes it impossible to derive the existence of a constitutional principle 'of capacity of the military forces to carry out their duties and the integrity of its members' that could eventually be balanced against other principles. From his perspective, these articles regard the Armed Forces from an organizational perspective without considering it as protectors of the institutional order as suggested by the judges in the dissenting opinion. ${ }^{35}$ One of the positive features of proportionality analysis instead of subsumption was that the judgement began a discussion about the constitutional principles of the Mexican legal order. As a concrete example, the role of the Armed Forces is one of the issues in which the Latin America constitutional context must be carefully analysed. Therefore, the public discussion generated as to the validity of a constitutional principle concerning the efficacy of the Armed Forces and its evolution since the 1917 Revolution when the Constitution was drafted and adopted in Mexico, is an important issue. This is one of the features of proportionality analysis as a rights adjudication doctrine that deals with principles considered open legal norms and, as a consequence, allows a broader debate about their content.

The second step of proportionality analysis is the presence of a rational connection between the means and the ends of the statute. The question is whether the declaration of 'useless or incompetent in the second category' when a soldier is diagnosed as being HIV

\footnotetext{
${ }^{33}$ Eyal BENVENisti, MARgin of APPRECIATION, CONSENSUS AND UNIVERSAL STANDARDS, 31 N.Y.U.J. INT’ L. L. \& POL., 843 (1999).

${ }^{34}$ José RAmÓn Cossio DíAZ, MiLitares CON VIH: CONTRA LA DISCRIMINACIÓN, 364 REVISTA NeXOS (APRIL 2008). Available at http://www.nexos.com.mx

${ }^{35}$ The dissent opinion underlines that the Armed Forces not only ensures the national security but also the internal security of the Mexican state and it has a role to play in order to overcome emergency situations.
} 
positive, and the consequential dismissal from the Armed Forces, is suitable in advancing the goal of the legitimate policy. This is an empirical question. It is suitable if it actually furthers the declared policy goal of the government. in this particular case, it is the efficacy of the military forces and the protection of the integrity of its members. The Supreme Court of Mexico established that the means used to achieve the aim of this law were inappropriate. The scientific and medical evidence proved that the immediate consequence of being considered useless or incompetent to work after being diagnosed as being HIV positive is wrong and, moreover, does not further any Mexican public health policy with regards to HIV. In order to provide a solid argument, the Supreme Court of Mexico alluded to the official public policy subscribed by the Mexican Government in order to prevent and control infections of HIV in the population. ${ }^{36}$ The Court also invoked international documents relating to the prevention and treatment of HIV infections such as the "Rights and Humanity Declaration and Charter on HIV and AIDS" and the "Declaration of Commitment on HIV and AIDS." "37 The real novelty of this judgement in the Latin American constitutional context, and a demonstration of one of the positive features of proportionality analysis as a judicial tool for rights adjudication, was the role given to medical and scientific data as extrinsic evidence. The Court requested information about HIV and AIDS from two experts of the 'National Scientific Academy of Mexico, ${ }^{38}$ The report of the two experts included information regarding the period in which the infected person fails to show symptoms, the dangers of transmission and the necessity of educational campaigns in order to reduce misinformation, prejudice and a culture of discrimination against individuals diagnosed as HIV positive. The legal consideration of this information could have been premised under two methods. One option was its consideration under the traditional parameter of evidence rules, where only the facts are at stake. Alternatively, it may be considered in the adoption of a new perspective contemplating proportionality analysis as a mechanism where the scientific perspective informs the judge and permits them to decide whether there is a rational connection between the means used by the law and the ends pursued. The argument here is that the existence of proportionality analysis instead of subsumption, as a rule-based mechanism, allowed the court to better deal with unforeseen facts, like the medical evidence either not known or ignored at the time when the statute was enacted by the Mexican legislature.

The third step, called the least drastic means element, requires that the statute must impair, damage, or harm the right as little as possible. In this case, an examination of the objective of the statute may determine the concrete situation to ascertain the most reasonable option that would least damage the right. However, judges may be required to collect information, supporting the view that proportionality analysis is a dialogue between the courts, political representatives and

\footnotetext{
${ }^{36}$ Mexican Official Standard, Nom-010-SSA2-1993, Official Gazette January $17^{\text {th }}, 1995$.

37 "Rights and Humanity Declaration and Charter on HIV and AIDS," Documents E/CN.4/1992/82, Human Rights Commission and the "Declaration of Commitment on HIV/AIDS," Document A/S-26/L.2 approved by the General Assembly of the United Nation on August $2^{\text {nd }}, 2001$.

${ }^{38}$ A discussion about the incorporation of extrinsic evidence in Miguel CARBOnell, SOBRE Virus, BACTERIAS Y JuECES, 364 REvista NeXOS (APRIL 2008). Available at http://www.nexos.com.mx
} 
wider society. In cases where an alternative measure would achieve the same goal with less infringement of the right, the initial measure must be declared unconstitutional. Nevertheless, it is important to acknowledge that the legislature has a margin of appreciation to decide between different measures to achieve a goal. The main problems the Court must decide upon will appear when the end-result of the legislation is uncertain, unclear or dependent upon future events.

Through this step, the present case posed a more difficult question as to whether a soldier is 'useless or incompetent' after being diagnosed as being HIV positive and if the enforced retirement from the armed forces is necessary. A measure is only necessary if there is no less restrictive, but equally effective, measure available to achieve the intended policy goal. The third step established that the law and the differentiation imposed in it were disproportionate because there were alternative methods where limitations upon the fundamental principles at stake (equality and non-discrimination based on health reasons) could have been better protected for Esteban Cabrera. One alternative solution would have been to move the soldier to a new administrative function inside the military forces.

The fourth step in proportionality analysis requires a proper relationship to be established between the means and the goals of the statute. This step is called 'proportionality in a narrow sense' and is focused upon balancing the factual limitation of the human right infringed and the attainment of the statute's objective. Rather than being a comparison, it weighs the impact upon the individual if the infringements are effective against the impact upon the societal interest if the measure is not adopted. Its importance has been challenged. Even supporters of proportionality analysis do not agree about its importance and its role in the balancing formula as a whole. Interestingly, the Supreme Court of Canada in 2007 in Canada (Attorney General) $v$. JTI-Macdonald Corporation, defended the importance of the fourth step of proportionality analysis by saying that: "Although cases are most often resolved on the issue of minimal impairment, the final inquiry into proportionality of effects is essential. It is the only place where the attainment of the objective may be weighed against the impact on the right. If rational connection and minimal impairment were to be met, and the analysis was to end there, the result might be to uphold a severe impairment on a right in the face of a less important objective."39

As a former judge of the German Constitutional Court, Dieter Grimm defends the central role of the fourth step of proportionality analysis by saying that this is the way in which to give full effect to fundamental rights and ensuring care as to what is allocated to each side of the scale. It is logical to assume that a comparison is required between the advantages and disadvantages of the objectives pursued and the limitations placed upon particular constitutional rights. Grimm describes this step as being a comparison between the losses to the infringed right if the law is upheld and the losses to the value protected by the law if the fundamental right prevails. For Grimm, the analysis is a contextual one and, therefore, can involve accusations of courts behaving as 'policy makers."

\footnotetext{
${ }^{39}$ CANADA V. JTI - MACDONALD CORP., [2007] 2 S.C.C.R. 610

40 Dieter Grimm, Proportionality in Canadian and German Constitutional Jurisprudence, 57(2) UNIVERSITY OF TORONTO LAW JOURNAL, 382, 393-94 (SPRING 2007).
} 
It is important to highlight the conflict between proportionality based on an analytical structure and the problem of incommensurability in balancing, as one of the most typical critiques of balancing. ${ }^{41}$ Aleinikoff describes this challenge as being the difficulty in identifying a common currency that allows balancing with the same scale values when constitutional principles are certainly different. ${ }^{42}$ The response provided by Robert Alexy is that the issue at stake in proportionality analysis is not 'direct comparability'. What is at stake is the existence of elements that allow a comparison, as proportionality assesses each principle in comparison with the ideal for that legal order. Therefore, the relevant question considers the seriousness of and harm caused by the infringement of each principle in respect to the core essence of that right in that particular constitutional setting. For Alexy the common point of view to solve the collision between rights is provided by the constitution. ${ }^{43}$ For Barak the common base for comparison is provided by the societal margin of importance of a given human right. ${ }^{44}$

In the current case, the fourth step of 'Proportionality stricto senso' analyzed whether the increase in operational effectiveness of the armed forces by prohibiting HIV infected individuals from serving was balanced, justified and proportionate by the degree of interference in the applicant's right to equality and non-discrimination based on health reasons. The Supreme Court of Mexico considered the law to be disproportionate. The examination at this step included following Alexy's weight formula. First, an assessment as to the intensity of interference of the principles at stake (the interference with the efficacy of the Mexican armed forces) was considered minimal by the majority. On the contrary, the interference with the right to equality and non discrimination based on health reasons of Esteban Cabrera was considered serious. Second, the concrete weight of the potentially-violated principles concluded that the medical evidence and the public policy interest in fostering a non-discriminatory culture made it obvious that the principle of equality and non-discrimination had a higher weight in the Mexican legal order. The debate as to the actual existence of the principle of military efficacy also proved that this is a principle with lower weight in this particular factual situation.

The alternative normative solution provided to overcome collisions in such constitutional cases in Latin America has been categorization, a rule-based system, with one of the principles having superiority in the hierarchy of rights to the exclusion of the other. The dissenting opinion in this case represented this adjudication mechanism. The main problem with categorization, as an adjudication technique, is that it gives absolute preference to one of the constitutional rights at stake. As an example, the dissenting opinion claimed that the prevailing constitutional right should have been the efficiency of the armed forces without consideration of the other possible

41 Carlos Bernal Pulido, The Rationality of Balancing, 92(2) Archiv Fuer Rechts- Und SOZIALPHILOSPHIE, 195, 200-8 (APRIL 2006).

${ }^{42}$ Alexander Aleinikoff, Constitutional Law in the Age of Balancing, 96(5), Yale L. J., 943, 973 (April 1987).

${ }^{43}$ ALEXY, supra note 7, at 442.

${ }^{44}$ BARAK, supra note 4, at 17. 
constitutional rights in collision, namely the right to equality and non-discrimination based on health reasons of Esteban Cabrera. ${ }^{45}$ This resulted in an intense public debate with the dissenting judges being accused of deciding the case based on their prejudices, of being ignorant by refusing to accept scientific and medical evidence regarding HIV, and having disregard for international treaties signed by Mexico. ${ }^{46}$

\section{CONCLUDING THOUGHTS}

First, we should acknowledge that proportionality analysis is a complex analytical method that would demand many considerations by the courts. This would include; judicial enquiry into constitutional history, knowledge about the actual standpoint of the social agreements consecrated in the constitution, a vast expertise about the public policies implemented by the government, a serious commitment to international obligations assumed by the state, and important engagement in extensive constitutional comparative studies. The idea of the legitimacy of comparative studies, although extremely interesting, is outside the scope of this paper. I believe that courts, by applying proportionality analysis even in this structured analytical form, are engaged in substantive value choices. Arguments contrary to this, like those developed by David Beatty suggesting that the method is neutral and driven by facts claiming that 'judges have no say on the worth of what is put on each side of the balance', are problematic in my opinion. ${ }^{47}$ Beatty thinks that pragmatism does a better job because facts are seen as better sources to decide cases as they have certainty, predictability and reality that permits a technique based on measurements and analysis. ${ }^{48}$ This approach using factual data is problematic because it is important to consider that judicial discretion not only involves the interpretation of legal norms, but entails the interpretation of facts as highlighted by Kim Lane Scheppele. ${ }^{49}$ I think that the factual perspective empowers the role of judges in the proportionality analysis; however, interpretation by judges is a misuse of judicial discretion. Discretion is about making choices and acknowledging the principles valid in their society. Obviously, this is the great challenge judges are confronted with but I do not see how a factual analysis or the proportionality technique could avoid this step.

Second, it remains to be answered why the efforts of the Mexican Supreme Court were directed at proving that balancing had always been part of the Mexican adjudication system and

\footnotetext{
45 Astonishingly, the dissenting judges in a sixty pages minoritarian judgement did not name Soldier Esteban Cabrera once.

${ }^{46}$ CARBONELL, supra note 38.

${ }^{47}$ BEATTY, supra note 28, at 167.

${ }^{48}$ BEATTY, supra note 28 , at 73 .

${ }^{49}$ Kim LANE SCHEPPELE, MANNERS OF MANAGING THE REAL, 19(4), LAW \& SOCIETy INQUIRY, 995 (AUTUMN 1994 ).
} 
that proportionality analysis in its structured four steps form did not represent a new methodology in rights adjudication claims. The reasons to reject adopting proportionality through a migration could include the fear of judicial activism in a system that traditionally left less room for judicial power and claims to the erosion of a state's sovereignty. This can be regarded as a strategic move to render the adoption of the principle of proportionality successful in the Mexican juridical order, partially avoiding the problems associated with the migration of constitutional mechanisms. ${ }^{50}$ Nevertheless, it is important to demonstrate awareness of the challenges posed by the migration of such a mechanism. Sujit Choudhry devoted an entire volume of essays to examine the actual challenges of the migration of constitutional ideas. ${ }^{51}$ Neil Walker argued in the same volume that migration leaves the door open to the adoption and adaptation of the 'recipient' legal country and does not connote ownership of the contributor. ${ }^{52}$

Objections to courts engaging with foreign ideas are currently being debated in the constitutional realm with concerns normally expressed as to the implications on state sovereignty. This short-sighted perspective has recently been challenged through a conceptual and theoretical shift of perspectives in constitutionalism. ${ }^{53}$ Paradoxically, proportionality analysis is structured in a way that considers the local legal context relevant and values its influence in the balancing operation at stake.

\footnotetext{
50 To the best of my knowledge the Supreme Court of Mexico adopted through the 'juicio de amparo en revisión $1659 / 2006$ ' in 2007 for the very first time the German structured form of proportionality analysis.

${ }^{51}$ Sujit Choudhry,ED., Migration of CONSTItUTIONAL IDEAS (CAMBridGE University Press, 2007)

52 NeIL WALKER, THE MIGRATION OF CONSTITUTIONAL IDEAS AND THE MIGRATION OF THE CONSTITUTIONAL IDEA, 316, In Migration of CONSTitutional IDEAS (SuJit CHOUdhry ED. CAMBridge University Press, 2007).

53 Nicholas TSAgourias, ED., TRANSNATIONAL CONSTITUTIONALISM: INTERNATIONAL AND EUROPEAN Perspectives (CAMBridge University PRESS, 2007).
} 